\title{
Soft Tissue Sarcoma of the Abdomen and Thoracic Visceral Organs cM1 TNM Finding v8
}

National Cancer Institute

\section{Source}

National Cancer Institute. Soft Tissue Sarcoma of the Abdomen and Thoracic Visceral

Organs CM1 TNM Finding v8. NCI Thesaurus. Code C136728.

Soft tissue sarcoma of the abdomen and thoracic visceral org ans with distant

metastases. (from AJCC 8th Ed.) 